\title{
FAKTOR-FAKTOR YANG MEMPENGARUHI MARGIN PEMASARAN SAPI POTONG DAN DAGING SAPI DI KABUPATEN ACEH BESAR
}

\section{FACTORS EFFECTED OF MARKETING MARGIN ON CATTLE AND BEEF CATTLE IN ACEH BESAR REGENCY}

\author{
Hendra Koesmara*, Sudi Nurtini, dan I Gede Suparta Budisatria \\ Fakultas Peternakan, Universitas Gadjah Mada, Yogyakarta, 55281
}

Submitted: 27 March 2013, Accepted: 2 January 2015

\section{INTISARI}

\begin{abstract}
Penelitian dilakukan untuk mengidentifikasi bentuk saluran pemasaran, menghitung bagian harga yang diterima peternak dan pedagang perantara, menganalisis margin pemasaran perdagangan sapi potong. Penelitian dilaksanakan pada bulan Juni sampai Agustus 2011 di Kabupaten Aceh Besar Provinsi Aceh. Metode yang dilakukan dalam penelitian ini adalah metode survei dan pengamatan langsung di lapangan serta mengadakan wawancara dengan menggunakan kuesioner kepada responden yang terdiri ataspetani peternak sapi potong dan pedagang perantara.Sampel seluruhnya berjumlah 420 respondenyang terdiri dari petani peternak 270 responden, pedagang perantara105 responden, dan konsumen akhir atau pedagang daging 45 orang, masing-masing diambil dari 3 kecamatan. Lokasi penelitian ditentukan secara purposive sampling method yaitu Kecamatan Seulimeum, Suka Makmur dan Kuta Baro. Hasil penelitian menunjukkan terdapat 2 saluran pemasaran, saluran pemasaran I dari peternak ke konsumen akhir melalui 2 pedagang perantara yaitu belantik (mugee) dan pedagang daging, sedangkan saluran pemasaran II dari peternak ke konsumen akhir melalui 1 pedagang perantara yaitu pedagang daging. Pada saluran pemasaran I mugee mendapatkan share pendapatan $24,89 \%$ dengan share biaya $10,38 \%$, sedangkan pedagang daging mendapatkan share pendapatan $47,70 \%$ dengan share biaya $17,03 \%$. Pada saluran pemasaran II pedagang daging mendapatkan share pendapatan $83,00 \%$ dengan share biaya $17,00 \%$. Pada saluran pemasaran I margin pemasaran pada mugee sebesar Rp1.026.293,10/ekor dan pada pedagang daging sebesar Rp1.883.045,98/ekor, sedangkan pada pemasaran jalur II pedagang daging sebesar Rp2.944.838,00/ekor. Koefisien determinasi $\left(\mathrm{R}^{2}\right)$ sebesar 0.337321 yang berarti margin pemasaran ternak sapi dapat dijelaskan secara bersama-sama sebesar $33,73 \%$ oleh biaya pemasaran, harga di tingkat peternak dan jumlah pedagang perantara. Hasil pengujian terhadap biaya pemasaran $\left(x_{1}\right)$ berpengaruh nyata $(P<0,05)$ terhadap margin pemasaran, harga di tingkat peternak $\left(x_{2}\right)$ berpengaruh sangat nyata $(P<0,01)$ terhadap margin pemasaran dan jumlah pedagang perantara $\left(x_{3}\right)$ tidak berpengaruh terhadap margin pemasaran. Kesimpulan penelitian ini adalah jalur pemasaran langsung ke pedagang daging memberi pendapatan kepada pedagang namun belum tentu memberi pendapatan kepada peternak.
\end{abstract}

(Kata kunci: Kabupaten Aceh Besar, Margin pemasaran, Saluran pemasaran, Ternak sapi)

\section{ABSTRACT}

This research identified the forms of share market, to calculate the price received by farmers and middlemen, and analyze marketing margins of beef cattle market. This research was conducted in June to August 2011, in Aceh Besar regency of Aceh province. The method used in this study was a survey method and field direct observations and interviews using questionnaires to farmers, middlemen (mugge) and meat traders respondent. The number of samples were 420 respondents, including 270 respondents of livestock farmers, 105 respondents of middlemen (mugee) and 45 respondents of meat traders (final consumer)from the three districts. This study used regression analysis to determine the effect of variables simultaneously observed the marketing margin. The results showed there were 2 channel marketings, channel marketing I of farmers to the final consumer through two market participants were mugee and meat traders, while the marketing channel II from farmers to consumers through one market participants that was meat traders. In marketing channels I mugee get income share $24.89 \%$ with $10.38 \%$ share of the cost, while the meat traders got incomeshare $47.70 \%$ with $17.03 \%$ share of the cost. In marketing channels II meat tradersgot income share $83.00 \%$ with $17.00 \%$ share of the cost. In marketing channels I mugee marketing margin of Rp1,026,293.10/head and the meat traders of Rp1,883,045.98/head, while the meat traders of $R p 2,944,838.00 /$ head. The coefficient ofdetermination $\left(R^{2}\right)$ equalto 0.337321 , which

\footnotetext{
* Korespondensi (corresponding author):

Telp. +62 8136004 1987, E-mail: koesmarahendra@gmail.co.id
} 
means cattle marketing margin could be explained jointly by $33.73 \%$ by the marketing costs, the price at the farmer level and the number of middlemen. The test results of the marketing costs (x1) significantly $(P<0.05)$ on the marketing margin, the price at the farmer level $(x 2)$ was highly significant $(P<0.01)$ on the marketing margin and the number of middlemen $(x 3)$ didnot affect the marketing margin.

(Keywords: Cattle, District of Aceh Besar, Market share, Marketing margin)

\section{Pendahuluan}

Propinsi Aceh terletak di bagian paling ujung pulau Sumatera yang sekaligus merupakan ujung paling barat dari gugusan Kepulauan Indonesia. Perkembangan usaha peternakan sangat memberikan harapan karena luasnya padang rumput yang tersedia yang tersebar di seluruh daerah. Secara tradisional turun-temurun penduduk setempat mata pencahariannya sebagai petani sekaligus sebagai peternak. Komoditi pertanian yang menjadi andalan di Kabupaten Aceh Besar adalah produk peternakan khususnya sapi potong yang berbasis pada peternakan rakyat, yang telah memberikan kontribusi cukup besar dalam memenuhi kebutuhan pangan hewani dan menunjang perekonomian rakyat. Sumitra (2013) menyatakan bahwa secara nasional, Indonesia masih belum mampu mencukupi kebutuhan permintaan daging sapi tersebut, sehingga salah satu cara untuk mengatasi kekurangan daging tersebut maka pemerintah membuka kran import sapi hidup maupun daging sapi (beku) dari negara lain. Langkah yang diambil pemerintah untuk mengatasi hal tersebut adalah dengan menetapkan program kecukupan daging 2014. Dalam mencapai program tersebut, diperlukan terobosan yang efektif dan dukungan yang nyata dari pemerintah dan masyarakat, khususnya yang bergerak di bidang usaha sapi potong, sedangkan menurut BPS (2009) pada tahun 2008 populasi sapi potong di Propinsi Aceh berjumlah 673.441 ekor dengan produksi daging sapi $7.339 .717 \mathrm{~kg}$, sedangkan di Kabupaten Aceh Besar jumlah populasi sapi potong adalah 105.533 ekor dengan jumlah pemotongan 11.337 ekor dan produksi daging sapi sebesar 1.307.426 kg.

Harga daging sapi di Aceh tergolong stabil dan hanya mengalami perubahan harga pada waktu-waktu tertentu yang biasa dikenal dikalangan masyarakat Aceh dengan sebutan meugang. Meugang adalah tradisi pemotongan hewan seperti sapi dan kerbau dalam masyarakat Aceh. Tradisi turun temurun ini dilakukan satu hari menjelang hari menyambut Ramadhan dan perayaan Idul Fitri serta Idul Adha atau terdapat tiga kali momentum meugang dalam setahun, yaitu meugang puasa, meuganguroe raya puasa (menjelang hari raya 'Idul Fitri) dan meuganguroe raya haji (menjelang hari raya Idul Adha).

Berdasarkan data dari Dinas Peternakan dan Kesehatan Hewan Propinsi Aceh (2009), kisaran harga daging sapi dari sapi impor diluar waktu meugang adalah Rp70.000-Rp75.000/kg, untuk harga waktu meugang mencapai Rp80.000-Rp90.000/kg. Perbedaan ini juga diikuti oleh harga daging sapi lokal yang mencapai Rp80.000Rp90.000/kg, kemudian harga di waktu meugang mengalami peningkatan hingga Rp100.000-Rp120.000/kg.

Coetzee et al., (2005), pemasaran ternak berperan penting pada proses transformasi skala rakyat menuju usaha yang komersial.

Saluran pemasaran di Kabupaten Aceh Besar pada umumnya cenderung meng-gunakan jalur yang tidak panjang, karena dalam sistem pemasarannya biasanya hanya melalui mugee. Jamilah (2010) menyatakan bahwa penjualan sapi potong dapat dilakukan secara langsung dengan pedagang daging. Peternak memberikan informasi kepada pedagang daging mengenai ternak yang akan dijual, penjualan dilakukan di lokasi peternak. Langkah ini sering dilakukan menjelang hari meugang. Pada hari-hari biasanya, jika lokasi peternak jauh dari pasar hewan, maka mugee mendatangi langsung ke lokasi peternak untuk membeli sapi potong, namun jika lokasi peternak dekat dengan pasar hewan maka peternak akan datang ke pasar hewan untuk menjual hewan ternaknya. Hasil kajian Rahmanto (2004) menyatakan bahwa analisis usaha peternakan sapi potong rakyat bahwa para peternak dalam memasarkan ternaknya memiliki ketergantungan yang tinggi pada jasa pedagang pengumpul dalam memasarkan ternaknya, meskipun tersedia fasilitas pasar ternak yang cukup memadai. Hal ini disebabkan oleh beberapa faktor, diantaranya: 1) skala usaha yang relatif kecil 
sehingga biaya angkutan ke pasar tidak efisien, 2) minimnya pengetahuan akses pasar oleh peternak, 3) transaksi didasarkan oleh pembeli, bobot badan ternak dan indikator-indikator lainnya terabaikan sehingga posisi tawar peternak lemah dan 4) adanya blantik dadung sebagai makelar dipasar yang berpotensi mengurangi pendapatan peternak.

Berdasarkan uraian diatas, penelitian ini bertujuan melakukan identifikasi terhadap bentuk saluran pemasaran sapi potong, menghitung bagian harga yang diterima peternak dan bagian harga yang diterima pedagang perantara dari tiap saluran pemasaran, serta faktor-faktor yang mempengaruhi margin pemasaran ternak sapi potong dimana hal ini dapat menggambarkan struktur, perilaku dan penampilan pasar yang berlaku dalam pemasaran ternak sapi potong di Kabupaten Aceh Besar.

\section{Materi dan Metode}

\section{Lokasi dan waktu penelitian}

Penelitian ini dilaksanakan di Kabupaten Aceh Besar, Provinsi Aceh. Lokasi penelitian ditentukan secara purposive sampling method yaitu Kecamatan Seulimeum, Suka Makmur, dan Kuta Baro. Pertimbangannya adalah daerah tersebut mempunyai populasi sapi siap potong yang paling banyak bila dibandingkan dengan daerah lain.

\section{Materi penelitian}

Materi yang digunakan dalam penelitian ini adalah petani peternak sapi potong dan pedagang perantara yang berperan dalam pemasaran ternak sapi. Jumlah sampel yang diambil dalam penelitian ini berjumlah 420 responden, yang terdiri atas petani peternak berjumlah 270 responden, pedagang perantara berjumlah 105 responden, dan konsumen akhir sapi potong atau pedagang daging berjumlah 45, yang masing-masing diambil dari 3 kecamatan di Kabupaten Aceh Besar (Kecamatan Seulimeum, Suka Makmur, dan Kuta Baro).

\section{Metode penelitian}

Metode yang dilakukan dalam penelitian ini adalah metode survei dan pengamatan langsung di lapangan serta mengadakan wawancara dengan menggunakan kuesioner kepada masing-masing responden. Data primer yang dikumpulkan dari responden peternak meliputi identitas peternak, sistem penjualan dan harga jual ternak, untuk responden pedagang perantara meliputi identitas pedagang perantara, jumlah pembelian, harga pembelian dan penjualan ternak, biaya pemasaran dan cara pembayaran, sedangkan responden konsumen akhir atau pedagang daging meliputi identitas pedagang daging harga pembelian ternak dan harga penjualan daging sapi. Data sekunder diperoleh dari Dinas Peternakan, Biro Pusat Statistik Kabupaten Aceh Besar serta literatur yang ada kaitannya dengan penelitian ini.

Pengumpulan data dilaksanakan pada bulan Mei sampai November 2011. Batasan definisi di dalam penelitian ini adalah sebagai berikut: sapi potong adalah seluruh sapi jantan siap potong yang dipasarkandiseluruh Kabupaten Aceh Besar, peternak adalah seseorang yang memiliki sapi potong untuk dijual kepada pelaku pasar lainnya, mugee adalah pedagang perantara atau blantik, pedagang daging adalah pelaku pasar yang membeli sapi potong dari peternak atau mugee untuk kemudian dipotong dan dijual dalam bentuk daging kepada konsumen akhir, dan konsumen akhir adalah seseorang yang membeli daging sapi potong dari pedagang daging.

\section{Analisis data}

Mengetahui saluran dan lembaga pemasaran ternak sapi dan daging sapi dilakukan dengan cara menelusuri mata rantai saluran pemasaran yang dilalui di tingkat petani sampai dengan konsumen akhir. Bailey dan Jayson (2007) menyatakan bahwa untuk mengetahui besarnya bagian harga yang diterima peternak (Sp) dari harga yang dibayar konsumen dapat dihitung dengan menggunakan model berikut:

$$
\mathrm{Sp}=\frac{\operatorname{Pf}}{\operatorname{Pr}} \times 100 \%
$$

\section{Keterangan:}

Sp: bagian harga yang diterima peternak

Pf: harga di tingkat petani

Pr: harga di tingkat konsumen.

Bailey dan Jayson (2007) lebih lanjut menyatakan bahwa analisis margin pemasaran dapat dihitung dengan menggunakan rumus: 


$$
\begin{aligned}
& M=P_{2}-P_{1} \text { atau } \\
& M=P_{r}-P_{f}
\end{aligned}
$$

Keterangan:

$$
\mathrm{M} \quad=\text { margin pemasaran }
$$

$\mathrm{P}_{2}$ atau $\mathrm{P}_{\mathrm{r}}=$ harga di tingkat konsumenakhir

$P_{1}$ atau $P_{f}=$ harga di tingkat peternak.

\section{Hasil dan Pembahasan}

\section{Analisis saluran pemasaran}

Saluran pemasaran terdiri dari seperangkat lembaga yang melakukan semua kegiatan yang digunakan untuk menyalurkan produk dan status kepemilikannya dari produsen ke konsumen. Saluran pemasaran merupakan sistem dari anggotaanggota saluran, produsen, perantara dan konsumen yang dihubungkan melalui proses pertukaran guna menciptakan nilai guna waktu dan tempat.

Hasil pengamatan di daerah penelitian menunjukkan bahwa pemasaran ternak sapi dan daging sapi melalui dua saluran pemasaran dan selalu berakhir pada pedagang daging, dimana konsumen akhirnya adalah konsumen daging. Saluran pemasaran ini relatif pendek karena sapi siap potong yang diperjualbelikan di pasar hewan yang ada di Kabupaten Aceh Besar hanya untuk memenuhi kebutuhan konsumen yang ada di Kota Banda Aceh dan Kabupaten Aceh Besar. Ada perbedaan karakteristik saluran pemasaran antara Kabupaten Aceh Besar dengan daerah lainnya, posisi jagal biasanya adalah bagian tersendiri sebagai lembaga pemasaran yang ada didalam saluran pemasaran. Hal ini sesuai dengan penelitian Yusuf et al. (2002) cit. Yusuf dan Nulik (2008), di dalam struktur perdagangan sapi potong, jagal merupakan bagian tersendiri sebagai lembaga pemasaran sebelum sampai ke konsumen akhir dalam bentuk daging, namun terdapat perbedaan di Kabupaten Aceh Besar dimana posisi jagal terintegrasi dengan pedagang daging. Adapun saluran pemasaran sapi siap potong di Kabupaten Aceh besar adalah saluran I yaitu peternak - mugee- pedagang daging konsumen daging, dan saluran II yaitu peternak - pedagang daging - konsumen daging.

Saluran pemasaran I di Kabupaten Aceh Besar terdiri dari 167 peternak, sedangkan sisanya sebanyak 103 peternak terkelompokkan dalan saluran pemasaran II.
Saluran pemasaran yang terdapat di Kabupaten Aceh Besar terdiri dari dua saluran pemasaran yaitu saluran tingkat dua, terdapat dua pedagang perantara sebelum barang tersebut sampai di tangan konsumen akhir dan saluran tingkat satu terdiri dari satu perantara penjualan, seperti pedagang eceran.

Heryadi (2011) menjelaskan bahwa terciptanya sistem pemasaran yang efisien serta menguntungkan baik peternak maupun konsumen, maka peternak harus memilih jalur pemasaran yang pendek. Penentuan harga ternak berdasarkan pada tafsiran berat karkas dan kondisi sapi, namun pada kenyataannya peternak kurang atau tidak dapat menafsirkan berat karkas, hal ini disebabkan karena kurangnya tingkat pengetahuan tentang kualitas ternak. Heryadi (2011) menjelaskan bahwa dalam pemasaran ternak sapi pada umumnya proses pembentukan atau penentuan harga selalu dikaitkan dengan urgensi kebutuhan uang tunai dari petani peternak; bila petani peternak sangat membutuhkan uang tunai, maka petani hanya bertindak sebagai price taker (penerima harga) saja, karena bargaining position (posisi dalam tawar menawar) lemah, bahkan tidak jarang terjadi praktek-praktek pemasaran yang merugikan petani peternak oleh para pedagang perantara atau blantik.

\section{Fungsi pemasaran}

Proses pemasaran ternak sapi di Kabupaten Aceh Besar diperoleh rerata harga jual sapi per ekor untuk masingmasing saluran pemasaran berbeda baik pada tingkat peternak, belantik atau mugee maupun pedagang daging. Suarda (2009) menyatakan bahwa fungsi pemasaran yang dilakukan meliputi: pembelian, penjualan, pembiayaan pengangkutan, pergudangan, penanggungan resiko, dan standarisasi serta informasi pasar. Pada saluran pemasaran I rerata harga jual sapi per ekor di tingkat peternak adalah Rp11.556.666,67, di tingkat mugee sebesar Rp12.237.931,3 dan di tingkat pedagang daging sebesar Rp14.120.977,01. Pada saluran pemasaran II rerata harga jual sapi per ekor di tingkat peternak adalah Rp13.224.305,56 dan di tingkat pedagang daging sebesar Rp16.169.444,44. Rerata harga jual sapi per ekor pada saluran pemasaran I dan saluran pemasaran II di tingkat peternak adalah 
sebesar Rp12.217.971,74, di tingkat mugee sebesar Rp12.237.931,03 dan di tingkat pedagang daging sebesar Rp15.145.210,73.

Saluran pemasaran I, harga pada tingkat peternak lebih rendah daripada harga di tingkat peternak pada saluran pemasaran II, hal ini disebabkan karena saluran pemasaran I mempunyai saluran pemasaran yang lebih panjang, sehingga proses penekanan harga pasar saluran pemasaran I lebih tinggi daripada saluran pemasaran II.

\section{Analisis bagian harga yang diterima peternak dan lembaga pemasaran}

Bagian harga saluran pemasaran I pada tingkat peternak yaitu sebesar $79,40 \%$, bagian harga pada tingkat mugee sebesar $7,27 \%$ dan harga pada tingkat pedagang daging yang sebesar $13,33 \%$, sedangkan pada saluran pemasaran II harga di tingkat peternak sebesar $81,79 \%$ dan pada tingkat pedagang daging sebesar $18,21 \%$. Saluran pemasaran I pada pasar ini tergolong saluran tingkat dua yang terdiri dari dua perantara penjualan dan saluran II tergolong menjadi saluran tingkat satu, dimana hanya terdapat satu pedagang perantara sebelum sampai ke konsumen akhir (Kotler et al., 2005).

Bagian harga yang diterima peternak pada kedua jalur pemasaran relatif lebih besar dibandingkan dengan lembaga pemasaran yang lainnya, hal ini tidak memberikan indikasi bahwa bagian harga yang diterima oleh peternak telah memadai karena peternak menanggung resiko lebih besar dan membutuhkan waktu yang lebih lama dibandingkan dengan lembaga pemasaran yang lainnya.

\section{Analisis margin pemasaran}

Margin pemasaran yang dihitung adalah merupakan selisih antara harga di tingkat pembeli dan harga di tingkat peternak. Jumlah besarnya margin pemasaran berbeda antara satu lembaga pemasaran satu dan satu lembaga pemasaran lainnya.

Emhar et al. (2014) menjelaskan bahwa margin pemasaran merupakan bagian biaya yang dibayarkan dan pendapatan yang diterima oleh setiap mata rantai yang terlibat dalam proses rantai pasokan. Distribusi sapi potong hidup hanya melibatkan satu perantara (saluran distribusi satu tingkat), maka mata rantai yang membayarkan dan menerima pendapatan adalah pedagang sapi potong hidup. Margin pendapatan yang diterima oleh pedagang adalah tinggi karena mata rantai yang terlibat sebagai perantara hanya satu yaitu pedagang sapi potong itu sendiri.

Rerata margin pemasaran pada saluran pemasaran I di tingkat belantik atau mugee sebesar Rp1.026.293,10 dan di tingkat pedagang daging sebesar Rp1.883.045,98 dengan jumlah rerata margin pemasaran Rp2.909.339,08, sedangkan pada saluran pemasaran II rerata margin pemasaran di tingkat pedagang daging adalah Rp2.944.838,00.

Tabel 1. Biaya dan pendapatan yang diterima lembaga pemasaran di Kabupaten Aceh Besar (\%/ekor) (the cost and income received by marketing agent Aceh Besar Regent (\%/head))

\begin{tabular}{ccccccc}
\hline \hline Saluran pemasaran & \multicolumn{3}{c}{ Mugee } & & \multicolumn{2}{c}{ Pedagang daging (butcher) } \\
${$\cline { 2 - 4 }$} }$ & $\%$ SB & \%SK & & \% SB & $\%$ SK \\
\hline I & 10,38 & 24,89 & & 17,03 & 47,70 \\
II & \multicolumn{2}{c}{-} & - & & 17,00 & 83,00 \\
Rerata (average) & 10,38 & 24,89 & & 17,02 & 65,35 \\
\hline
\end{tabular}

SB: share biaya (cost share).

SK: share pendapatan (income share).

Tabel 2. Analisis faktor-faktor yang mempengaruhi margin pemasaran (analysis of factors affecting marketing margin)

\begin{tabular}{lccc}
\hline \hline \multicolumn{1}{c}{ Variabel (variable) } & $\begin{array}{c}\text { Koefisien } \\
\text { (coefficient) }\end{array}$ & $\begin{array}{c}\text { t-statistik } \\
(\text { t-statistic })\end{array}$ & $\begin{array}{c}\text { Probabilitas } \\
(\text { probability) }\end{array}$ \\
\hline Konstanta (constanta) & 13.3870 & 73.4587 & $0.0000^{* *}$ \\
Biaya pemasaran (marketing cost) $\left(\mathrm{x}_{1}\right)$ & 0.0195 & 1.9656 & $0.0506^{*}$ \\
Harga di tingkat peternak (farmer price level) $\left(\mathrm{x}_{2}\right)$ & 0.0792 & 10.3801 & $0.0000^{* *}$ \\
Jumlah pedagang (number of trader) $\left(\mathrm{x}_{3}\right)$ & -0.0102 & -0.9700 & $0.3331^{\mathrm{ns}}$ \\
\hline
\end{tabular}

Koefisien determinasi $\left(\mathrm{R}^{2}\right)$ (coefficient of determination): 0.3373

F-statistik: 37.4983

** $\mathrm{P}<0,01 ;$ * $\mathrm{P}<0,05$, ${ }^{\text {ns }}$ Berbeda tidak nyata (non siginificant). 
Saluran pemasaran II mempunyai margin pemasaran yang lebih tinggi daripada jumlah margin pemasaran pada saluran pemasaran I, hal ini disebabkan karena saluran pemasaran II terjadi ketika kondisi meugang, selain itu sapi yang dijual di pasar hewan pada saat meugang adalah sapi dengan bobot badan yang besar dengan harga transaksi juga relatif tinggi. Kondisi seperti ini biasanya pedagang daging berkompetisi untuk membeli ternak sapi dengan langsung mendatangi peternak, sehingga menyebabkan margin pemasaran pada saluran pemasaran II lebih tinggi, meskipun saluran pemasaran II lebih pendek daripada saluran pemasaran I.

Saluran pemasaran I share biaya mugee sebesar $10,38 \%$ dengan share pendapatan yang diterima sebesar $24,89 \%$, sedangkan share biaya pedagang daging sebesar $17,03 \%$ dan share pendapatan yang diterima sebesar $47,70 \%$, sedangkan pada saluran pemasaran II share biaya pedagang daging sebesar $17,00 \%$ dengan share pendapatan yang diterima sebesar $83,00 \%$. Saluran pemasaran II lebih pendek daripada saluran pemasaran I, hal ini disebabkan karena pada saluran pemasaran II tidak melalui mugee. Saluran pemasaran II yang relatif lebih pendek inilah yang menyebabkan share pendapatan pada pedagang daging relatif lebih besar daripada share pendapatan pedagang daging pada saluran pemasaran I. Ratniati (2007) menyatakan bahwa pendapatan yang didapat sesuai dengan biaya pemasaran yang dikeluarkan oleh setiap lembaga pemasaran, dimana semakin tinggi biaya pemasaran yang dikeluarkan maka akan semakin tinggi pendapatan yang akan diperoleh oleh setiap lembaga pemasaran tersebut.

\section{Faktor-faktor yang mempengaruhi margin pemasaran}

Faktor-faktor atau variabel yang mempengaruhi margin pemasaran ternak sapi di Kabupaten Aceh Besar adalah biaya pemasaran, harga ditingkat peternak, dan jumlah pedagang perantara. Analisis faktorfaktor yang mempengaruhi margin pemasaran tersaji pada Tabel 2.

Tabel 2 menunjukkan bahwa koefisien determinasi $\left(R^{2}\right)$ sebesar 0,3373 yang berarti margin pemasaran ternak sapi dapat dijelaskan secara bersama-sama sebesar $33,73 \%$ oleh biaya pemasaran, harga pada tingkat peternak dan jumlah pedagang perantara.

Hasil pengujian terhadap biaya pemasaran $\left(x_{1}\right)$ berpengaruh nyata $(P<0,01)$ terhadap margin pemasaran, artinya bahwa semakin tinggi biaya pemasaran maka margin pemasaran akan semakin besar. Koefisien regresi 0,0195 (bertanda positif), artinya bahwa setiap kenaikan Rp1,00 biaya pemasaran dengan menjaga faktor lain konstan maka margin pemasaran akan meningkat sebesar Rp0,0195.

Hasil pengujian terhadap harga di tingkat peternak $\left(\mathrm{x}_{2}\right)$ berpengaruh sangat nyata $(P<0,01)$ terhadap margin pemasaran, artinya bahwa ketika terjadi kenaikan harga di tingkat peternak maka pedagang akan cenderung menetapkan harga jual kepada konsumen berikutnya lebih tinggi sehingga margin lebih besar. Koefisien regresi 0,0792 (bertanda positif) artinya bahwa setiap kenaikan $\mathrm{Rp} 1,00$ harga di tingkat peternak dengan menjaga faktor lain konstan maka margin pemasaran akan meningkat sebesar Rp0,0792, sesuai dengan penelitian Sumpe (2009) yang menyatakan bahwa semakin besar harga ditingkat konsumen maka margin pemasaran akan semakin besar. Hal ini memberikan indikasi bahwa peternak tidak memiliki kekuatan tawar pada saat transaksi, sehingga naiknya harga di tingkat konsumen tidak memberikan kenaikan harga yang berarti di tingkat peternak. Pemasaran perlu didukung oleh kelembagaan dan koperasi untuk menyebarkan informasi antar peternak (Girei et al., 2013). Disamping itu perlu adanya kelompok ternak untuk mendapatkan penyuluhan tentang pentingnya manajerial dan teknis dalam pemasaran ternak (Hangara et al., 2012).

\section{Kesimpulan}

Hasil analisis bagian harga saluran pemasaran I pada tingkat peternak yaitu sebesar $79,40 \%$, bagian harga pada tingkat mugee sebesar $7,27 \%$ dan harga pada tingkat pedagang daging yang sebesar $13,33 \%$, sedangkan pada saluran pemasaran II harga di tingkat peternak sebesar $81,79 \%$ dan pada tingkat pedagang daging sebesar $18,21 \%$. Rerata margin pemasaran pada saluran pemasaran I di tingkat belantik atau mugee sebesar Rp1.026.293,10 dan di tingkat pedagang daging sebesar Rp1.883.045,98 dengan 
jumlah rerata margin pemasaran Rp2.909.339,08, sedangkan pada saluran pemasaran II rerata margin pemasaran di tingkat pedagang daging adalah Rp2.944.838,00. Analisis dari faktor-faktor yang mempengaruhi pemasaran ternak sapi potong dan daging sapi di Kabupaten Aceh Besar, dapat disimpulkan bahwa biaya pemasaran dan harga ditingkat peternak adalah faktor-faktor yang mempengaruhi margin pemasaran secara nyata.

\section{Daftar Pustaka}

Bailey, N. and J. Lusk. 2007. Agricultural Marketing and Price Analysis. Prentice Hall.

BPS. 2009. Statistik Daerah Propinsi Aceh 2008. Badan Pusat Statistik Propinsi Aceh, Banda Aceh.

Coetzee, L., B. D. Montshwe and A. Jooste. 2005. The marketing of livestock on communal lands in the Eastern Cope Province: constraints, challenges and implications for the extension services. S. Afr. Agric. Ext. 34: 81-103.

Dinas Peternakan dan Kesehatan Hewan Propinsi Aceh. 2009. Buku Rencana Strategis Dinas Peternakan dan Kesehatan Hewan Propinsi Aceh 2010. Dinas Peternakan dan Kesehatan Hewan Propinsi Aceh, Banda Aceh.

Emhar. A., J. M. M. Aji, dan T. Agustina. 2014. Analisis rantai pasokan (supply chain) daging di Kabupaten Jember. Jurnal Berkah IImiah Pertanian 1: 5361.

Hangara, G. N., M. Y. Teweldemedhin and I. B. Groenewold. 2012. Assessment of the constraints of cattle supply chain management in Namibia: case study of Omahele Communal Farmers. African J. Agric. Research 7: 4876-4884.

Girei, A. A., B. Dire and B. H. Bello. 2013. Assesment of cost and returns of cattle marketing in central zone of Adamawa State, Nigeria. British J. Marketing Studies 1: 1-10.
Heryadi, A. Y. 2011. Pola pemasaran sapi potong di pulau Madura. Jurnal Sosial Ekonomi Peternakan 5: 38-46.

Jamilah. 2010. Analisis perilaku dan kinerja pasar serta alternatif kebijakan pengembangan sapi potong. Jurnal Aplikasi Manajemen 8: 1039-1053.

Kotler, P., S. H. Ang, S. M. Leong, dan C. T. Tan. 2005. Manajemen Pemasaran: Sudut Pandang Asia Edisi Ketiga. PT Indeks, Jakarta.

Rahmanto, B. 2004. Analysis of Livestock Beef Cattle Enterprise. ICASERD Working Paper. Pusat Penelitian dan Pengembangan Sosial Ekonomi Pertanian. Badan Penelitian dan Pengembangan Pertanian, Departemen Pertanian, Bogor.

Ratniati, N. K. 2007. Analisis sistem pemasaran ternak sapi potong PT Giant Great Livestock Company Lampung Tengah. Skripsi Institut Pertanian Bogor, Bogor.

Suarda, A. 2009. Saluran pemasaran sapi potong di Sulawesi Selatan. Jurnal Sains dan Teknologi 9: 113-118.

Sumitra, J., T. A. Kusumastuti, dan R. Widiati. 2013. Pemasaran sapi potong di Kabupaten Ogan Komiring Ilir Propinsi Sumatera Selatan. Buletin Peternakan 37: 49-58.

Sumpe, I. 2009. Faktor-faktor yang mempengaruhi ternak sapi potong di Kabupaten Manokwari. Jurnal IImu Peternakan 4: 93-98.

Yusuf dan J. Nulik. 2008. Kelembagaan ternak sapi potong di Timor Barat, Nusa Tenggara Timur. Jurnal Pengkajian dan Pengembangan Teknologi Pertanian 11: 132-144. 